\title{
Shared Decision Aids: Increasing Patient Acceptance of Long-Acting Reversible Contraception
}

\author{
Tracy P. George ${ }^{1,2}$, Claire DeCristofaro ${ }^{3,4, *}$, Bonnie P. Dumas ${ }^{3}$ and Pamela F. Murphy ${ }^{4}$ \\ 1 Department of Nursing, Francis Marion University, Florence, SC 29502, USA; \\ E-Mail: TGeorge@fmarion.edu \\ 2 South Carolina Department of Health and Environmental Control, Dillon, SC 29536, USA \\ 3 College of Nursing, Medical University of South Carolina, Charleston, SC 29425, USA; \\ E-Mail: dumasb@musc.edu \\ 4 Department of Behavioral Sciences, College of Health, Human Services, and Science, \\ Ashford University, San Diego, CA 92123, USA; E-Mail: pamela.murphy@ashford.edu \\ * Author to whom correspondence should be addressed; E-Mail: claire.decristofaro@ashford.edu; \\ Tel.: +1-828-545-9406.
}

Academic Editor: Richard H. Beinecke

Received: 2 February 2015 / Accepted: 3 April 2015 / Published: 10 April 2015

\begin{abstract}
Unintended pregnancies are an important public health issue. Long-acting reversible contraceptive methods (LARCs) are reliable, safe, highly effective methods for most women; however they are underutilized in the United States. Shared decision aids were added to usual care in five public health family planning clinics in the Southeastern United States, staffed by advance practice nurses and registered nurses. All five sites showed an increase in the use of LARCs during the time period that shared decision aids were used (results statistically significant to $p<0.001$ ). It is important for women to make informed choices about contraception, and shared decision aids can be utilized to support this decision making. This resource has been adopted for statewide use in all public health clinics, and implications for practice suggest that the use of shared decision aids is an effective method to support informed patient decision making and acceptance of LARC methods of contraception.
\end{abstract}

Keywords: long-acting reversible contraceptive methods (LARCs); shared decision aids; intrauterine devices (IUDs); contraceptive implants; patient education; public health nursing 


\section{Introduction}

It is important for women to make informed decisions about contraception without bias or coercion. Shared decision-making is a patient education approach that acknowledges the patient's preferences, allows the patient to make informed choices, shows respect for the patient's decisions, and is associated with improved satisfaction with healthcare decisions [1]. In addition, shared decision-making is often related to improved health outcomes [2]. Shared decision-making involves the patient and provider working together to reach a healthcare decision [3]; through the use of shared decision aids, patients are able to comprehend their choices and possible outcomes and participate more effectively in health care decision-making [4]. In this way, shared decision aids are tools that assist with the process of shared decision making.

The use of shared decision aids is prevalent in many areas of health care, and may include brochures, videos, or internet-based activities; they may be self- or provider-administered [5]. The use of shared decision aids regarding contraceptive choices has been associated with improved communication and more informed decision-making [6]. Currently, the Agency for Healthcare Research and Quality (AHRQ) provides patient-centered shared decision aid resources, such as the "SHARE" stepwise approach that includes patients in healthcare decision making by helping the patient compare options and evaluating patient preferences [7].

Unintended pregnancies are an important issue in health care today. Nearly half of all pregnancies in the United States are unintended, and the direct health care costs of those pregnancies are estimated to be $\$ 9.6$ to 12.6 billion annually [8]. Long-acting reversible contraceptive methods (LARCs), which include intrauterine devices (IUDs) and contraceptive implants, are highly effective types of reversible contraception, and limited effort is needed by the user for adherence. According to the Centers for Disease Control (U.S. Medical Eligibility Criteria for Contraceptive Use, 2010) and endorsed by the American College of Obstetrics and Gynecology (ACOG), there are few limitations or contraindications to the use of LARCs $[9,10]$. While the initial expense is higher, LARCs are also very cost-effective contraceptive methods [11]. Despite the positive benefits of LARCs, their use remains low. In the United States, IUD usage has grown from $0.8 \%$ to $5.6 \%$ from 1995 to the $2006-2010$ time period [12]. Globally, contraceptive implants and contraceptive injections are used by $3.4 \%$ of women, while $15.5 \%$ of women utilize IUDs [13]. Improved patient education, removal of financial barriers, and increased provider knowledge and training are necessary to expand the use of LARCs. As per ACOG, increased utilization of LARCs could reduce unintended pregnancy rates in the United States [10].

Contraceptive knowledge is an issue that related to LARC usage by women. Dempsey, Billingsley, Savage, and Korte [14] found that women who have increased knowledge about LARCs are more likely to choose them for contraception. In addition, women who receive effective counseling that includes the benefits and potential side effects of LARCs, are more likely to be satisfied with and continue these methods [11]. Furthermore, eighty-five percent of private and public sector family planning providers identified a need for improved contraceptive counseling to enhance contraceptive method utilization [15].

Arrowsmith, Aicken, Saxena, and Majeed [16] completed a systematic review of the literature on ways to increase the use of the copper IUD. Three studies reported that community-based contraceptive counseling and referrals resulted in increased use of the non-hormonal copper IUD (OR 2.0, 95\% CI 1.4 to 2.85). Two studies on antenatal counseling and uptake of the copper IUD were statistically significant 
(OR 2.33, 95\% CI 1.39 to 3.91). In one study, postpartum contraceptive counseling resulted in more women choosing the non-hormonal IUD (OR 5.73, 95\% CI 3.59 to 9.15).

Contraceptive counseling was also an important factor in several other studies. In a qualitative study of 20 nulliparous young women, using semi structured 1-h interviews, Brown, Auerswald, Eyre, Deardorff, and Dehlendorf [17] developed a process model for intrauterine contraception that focuses on the role of the provider. This model includes the following stages: initial awareness, initial reaction, information gathering, adoption, adjustment, and reassessment. Patients emphasized the importance of receiving comprehensive contraceptive counseling when making the decision to choose LARCs. In a cross-sectional descriptive survey of 1800 unmarried males and females, Dempsey et al. [14] found that patients with high IUD knowledge were six times more likely to be using a LARC (OR 6.3, 95\% CI 1.4-28.8).

In a prospective cohort study of 7637 women, Madden, Mullersman, Omvig, Secura, and Peipert [18] found that $78 \%$ of women at a community partner clinic who received the usual contraceptive counseling chose LARCs, while $72 \%$ at the university clinic who received structured contraceptive counseling provided by non-medical staff members decided to use LARCs. The differences between the groups were not significant (adjusted relative risk $0.98,95 \%$ CI $0.94-1.02$ ). In a prospective cohort study of 2500 women, Secura, Allsworth, Madden, Mullersman, and Peipert [19] found that $67 \%$ of women who were not on a contraceptive method chose LARCs once the barriers of patient education and cost were removed. Of those using LARCS, 56\% chose intrauterine contraception, while $11 \%$ chose the contraceptive implant. In a prospective cohort study of 7486 women who were offered contraceptives of their choice at no cost in the Contraceptive CHOICE Project, the failure rate for contraceptive injections and LARCs was 0.27 per 100 participant years, regardless of whether the person was under 21 years of age or over 21 years of age [20]. In comparison, participants who chose contraceptive rings, pills, or patches had a failure rate of 4.55 per 100 participant years, with higher rates in women under age 21 [20]. Among 1404 adolescents involved in the Contraceptive CHOICE prospective cohort study, the teen birth rate was decreased to 34.0 per 1000 , while the national teen pregnancy rate was 57.4 per 1000 teens. There were similar reductions in live births and induced abortion rates among the study participants (19.4 and 19.7 per 1000), as compared to national data (94.0 and 41.5 per 1000) [21].

In a qualitative study of 42 female patients, most patients desired a patient-centered approach to counseling, rather than a directive approach. Dehlendorf, Levy, Kelley, Grumbach, and Steinauer [22] found that patients desired to make the final decisions about contraception with input from providers. Patients also stated the need for verbal and written information on contraceptives, and they emphasized the role of social networks in their decisions about contraceptive methods.

According to the American College of Obstetrics and Gynecology (ACOG) Committee Opinion, providers should discuss LARCs as first-line contraceptive options for many women [10]. Comprehensive contraceptive counseling is an important factor in the adoption of LARCs by females of reproductive age. Many individuals are unaware of LARCs [23] unless health care providers present information about them, so it is important for advanced practice nurses to discuss LARCs as a contraceptive option in 2013, the counties studied in this project had low utilization of LARCs. In the three counties of the project, $1.63 \%$ to $2.67 \%$ of public health family planning females had IUDs, while $1.27 \%$ to $3.67 \%$ of the patients had contraceptive implants [24]. Furthermore, in 2012, the teen birth rates for the three counties were above the national average of 29.4 births per 1000 females, with a range 
of 35.1 to 67.1 births per 1000 females in the three counties [25]. In this public healthcare setting, nursing staff used shared decision aids in addition to regular care for three months to determine if the use of shared decision aids impacted the number of LARCs inserted over that time period.

\section{Experimental Section}

\subsection{Project Design}

This was a six-month pre-intervention/post-intervention quality improvement project at five public health family planning sites in three counties in the southeastern United States. Usual care of females, ages 13-45 years old, seeking contraception included verbal counseling by staff (nurses and nurse practitioners) as part of the review of consent documentation regarding contraceptive options. Shared decision aid brochures were added to usual care by the regular staff, and the number of LARCs inserted for three months prior to the intervention was compared with the number of LARCs inserted during the three-month intervention period.

Most of the public health nurses in the five sites have completed additional training to expand the general skill-set to include advanced assessment and performance of physical examinations skills. Integrated Preventative Health RNs provide contraceptives under standing orders and additionally are authorized by the state's Nurse Practice Act to practice in an expanded role. The nurse practitioners are either family nurse practitioners or women's health nurse practitioners, and in addition to performing exams, they are all trained to insert IUDs and contraceptive implants at the sites. Nurse practitioners are available at the sites at least one day per week.

\subsection{Institutional Review Board Approval}

The Institutional Review Board for the state health department, which is the administrative body for the family planning program, approved this project prior to implementation.

\subsection{Development and Implementation of Shared Decision Aids}

Guidance for nurses' usual care when counseling females of reproductive ability on contraceptive options was provided by the current version of Title X program guidelines, published by the United States Department of Health and Human Services [26]. In addition, the five clinics shared the same public governing agency, which has a policy on patient education that guides contraceptive counseling [27]. Adhering to this policy, the nurses and nurse practitioners utilize a collaborative approach to counseling patients, which is consistent with shared decision making. As per agency guidelines, all written literature must be appropriate for the person's age, educational level, language, and sociocultural backgrounds [27].

Prior to the project, a one-page sheet describing all the contraceptive methods was utilized in counseling patients. Women were allowed additional information on any contraceptive methods. The two shared decision aids used for this project were designed by one of the project authors (TPG), in conjunction with local, regional, and state agency personnel, as well as input from community members and public health patients. The shared decision aids are color, trifold brochures that utilize pictures and bullet points, and each of these were made available in both English and Spanish language versions (translation provided by professional translators employed by the state) (See Figures 1-4). 


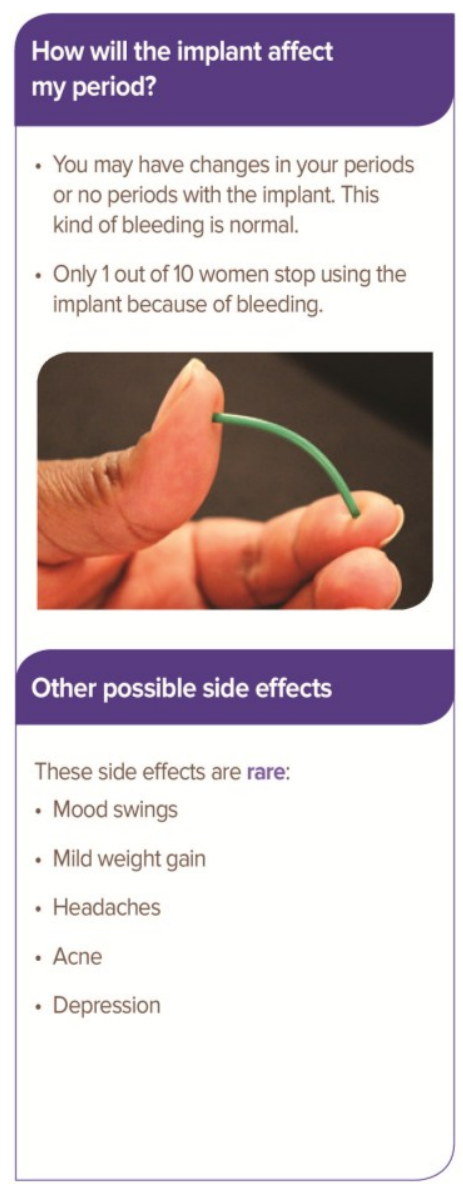

\section{What is the implant?}

- It is a small, flexible tube inserted into your upper arm.

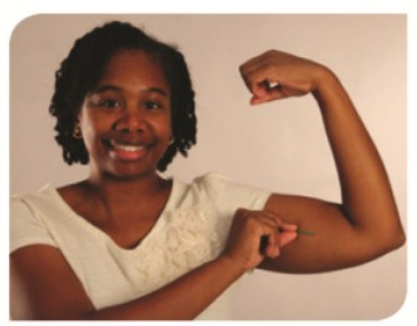

- It lasts up to 3 years.

- It contains a hormone that can keep you from getting pregnant.

- It is over $\mathbf{9 9 \%}$ effective, so you are not likely to get pregnant with the implant.

- You don't have to do anything to check the implant once it is placed in your arm.

- You need to have it removed by your health care provider after 3 years.
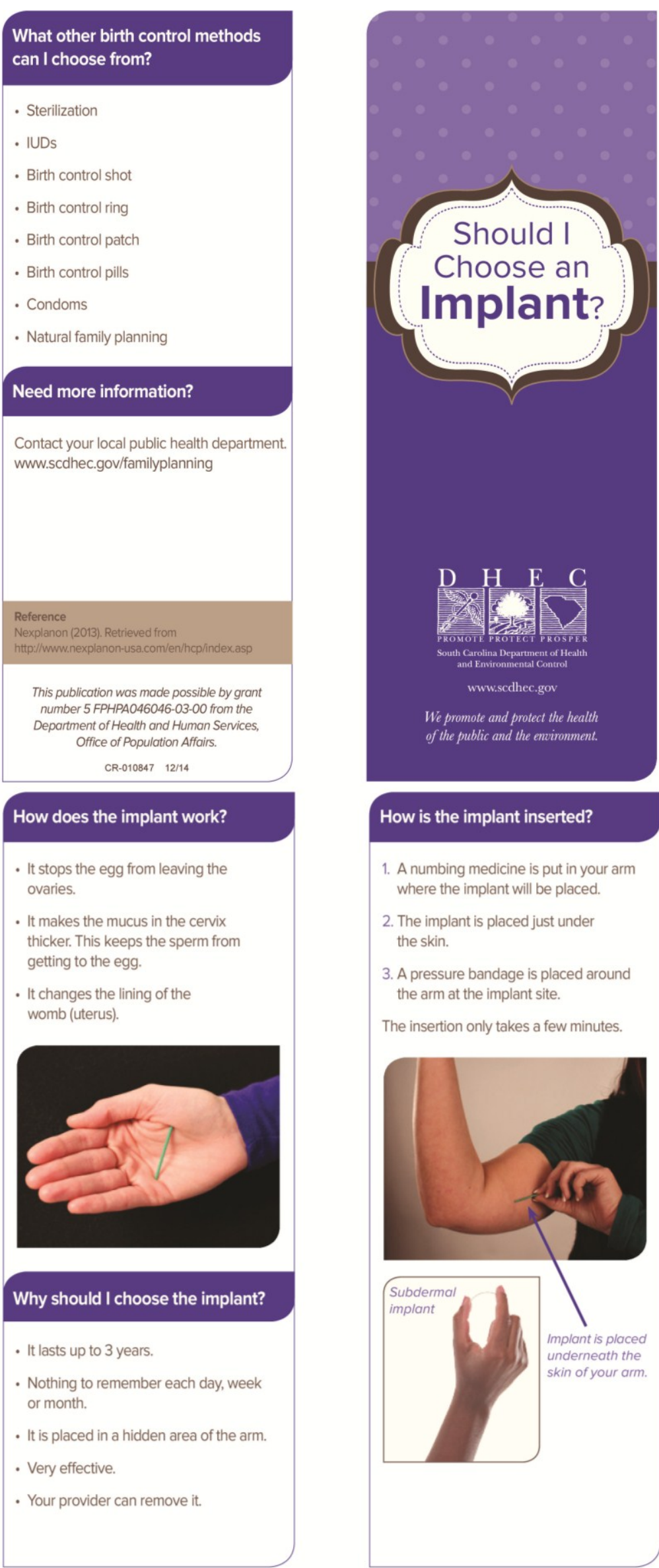

How is the implant inserted?

1. A numbing medicine is put in your arm where the implant will be placed.

2. The implant is placed just under the skin.

3. A pressure bandage is placed around the arm at the implant site.

The insertion only takes a few minutes.

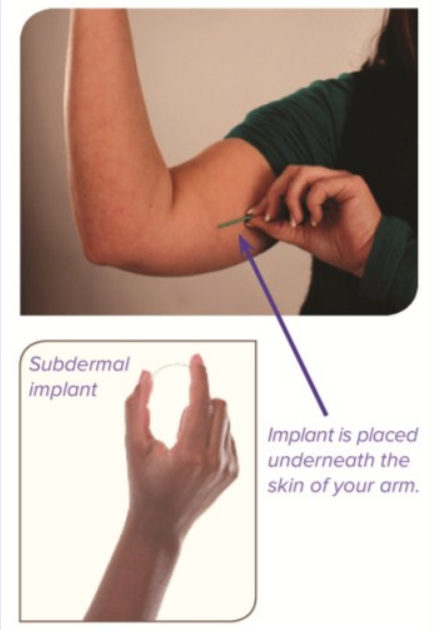

Figure 1. Shared Decision Aid, English Language: “Should I Choose an Implant?” [28]. 


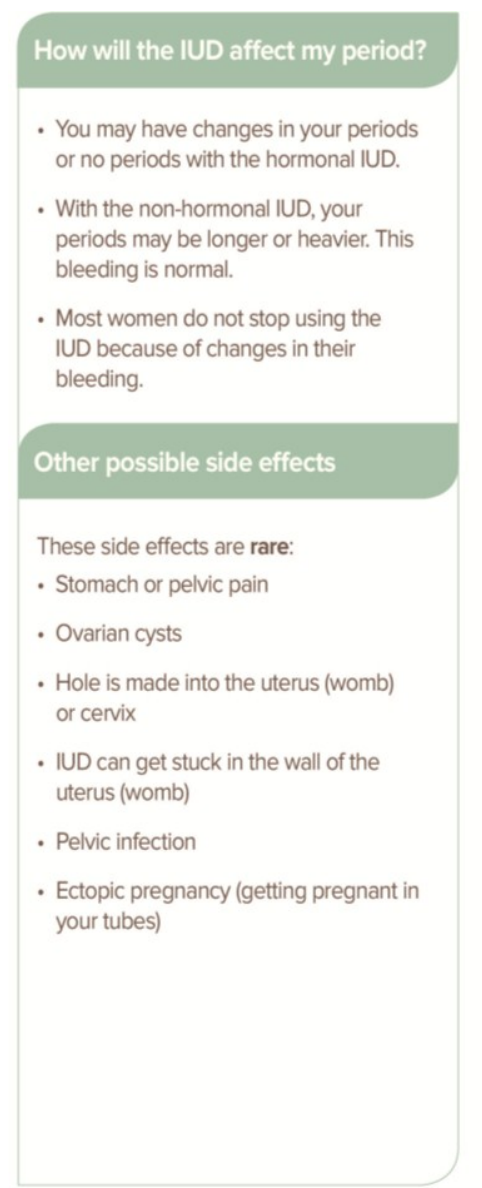

What is an IUD?

- T-shaped plastic piece that is placed in the uterus (womb).

- It lasts from 3 to 10 years.

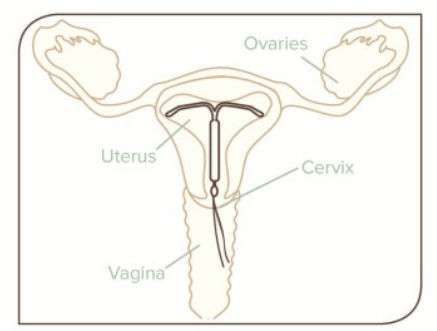

There are two types of IUDs

\section{Hormonal IUD}

- It contains a hormone that prevents pregnancy.

- It lasts 3 to 5 years.

- It is over $\mathbf{9 9 \%}$ effective.

Non-Hormonal IUD:

- It contains copper.

- It lasts up to 10 years.

- It is over $\mathbf{9 9 \%}$ effective
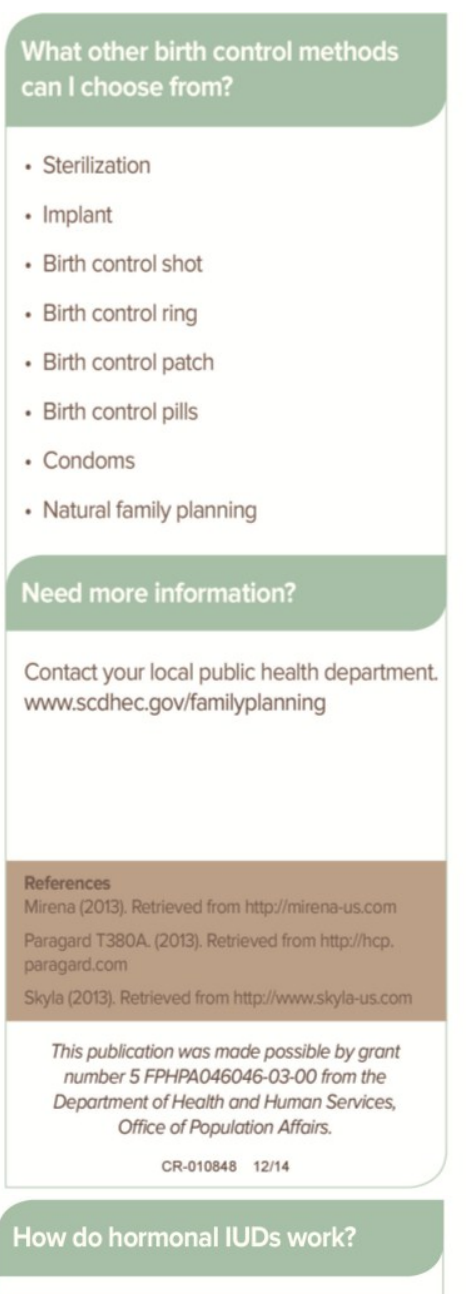

\section{- Thickens cervical mucus}

- Decreases sperm movement

- Makes lining of uterus (womb) thinner

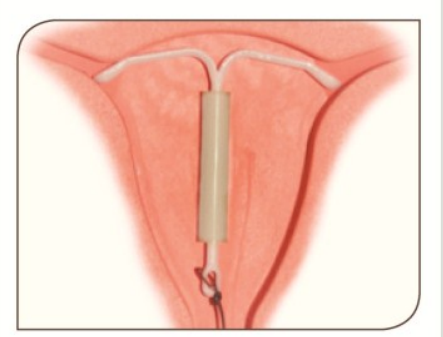

How do non-hormonal IUDs work?

- Keeps the sperm from reaching and fertilizing the egg

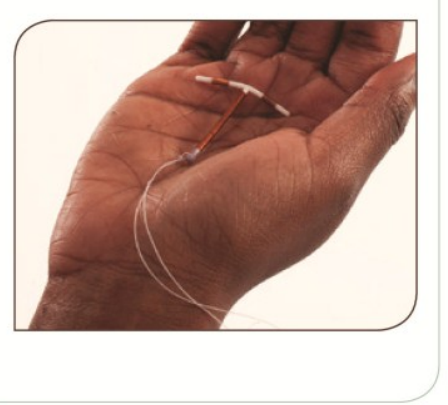

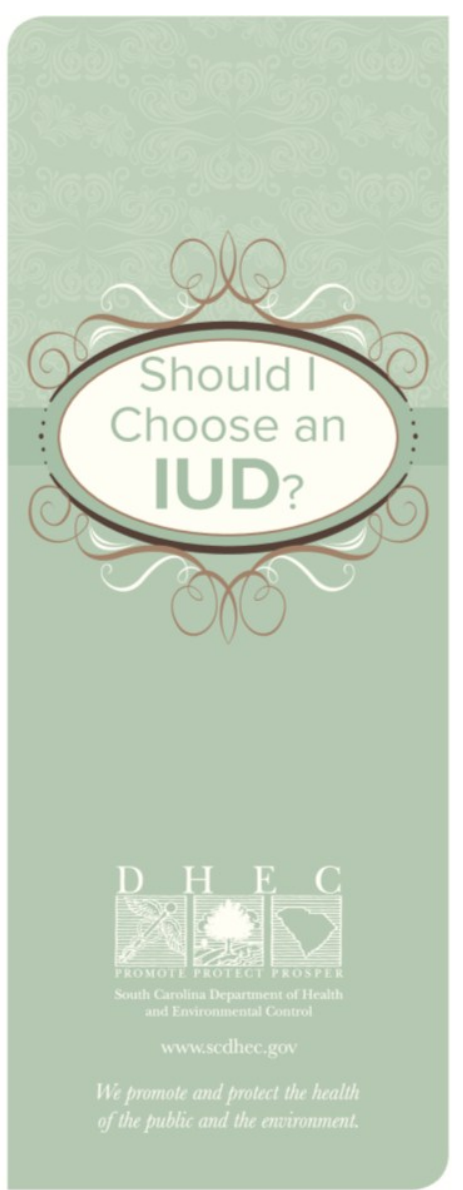

Why should I choose an IUD?

- It lasts from 3 to 10 years.

- Nothing to remember to take every day, week, or month.

- You only need to check the IUD once a month.

- Very effective.

- It can be removed by your health care provider.

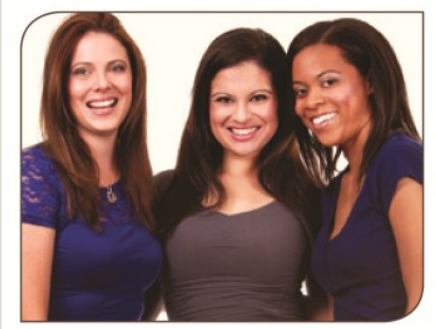

How is the IUD put in?

- It is inserted through the vagina into the uterus (womb).

- This can be done in the health department or your provider's office.

- It only takes a few minutes .

- You may have some cramps and spotting for a few days.

Figure 2. Shared Decision Aid, English Language: "Should I Choose an IUD?” [29]. 


\section{¿Cómo afectará mi período} el implante?

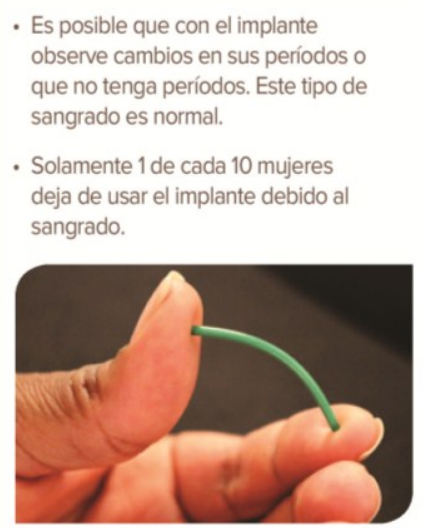

Otros efectos secundarios posibles

Estos efectos secundarios son raros

- cambios de humor

- aumento leve de peso

- dolores de cabeza

- acné

- depresión

Qué es un implante?

- Es un tubo flexible y pequeño que se inserta en la parte superior del brazo.

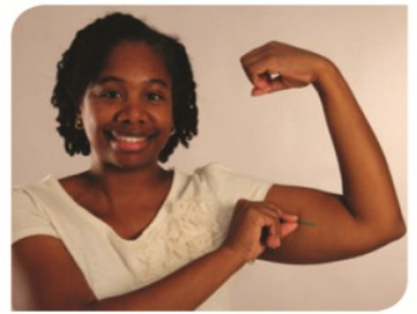

- Dura hasta 3 años.

- Contiene una hormona que puede evitar que quede embarazada.

- Su eficacia supera el $\mathbf{9 9} \%$, por lo que es probable que no quede embarazada con el implante.

- No tiene que hacer nada para revisar el implante una vez que se lo hayan colocado en el brazo.

- Después de 3 años un proveedor de atención médica tendrá que quitárselo.

\section{¿Entre cuáles otros métodos}

anticonceptivos puedo elegir?

- esterilización

- dispositivo intrauterino (DIU)

- inyección anticonceptiva

- anillo anticonceptivo

- parche anticonceptivo

- pildoras anticonceptivas

- condones

- planificación familiar natural

\section{¿Necesita más información?}

Comuníquese al departamento local de salud pública.

www.scdhec.gov/familyplanning
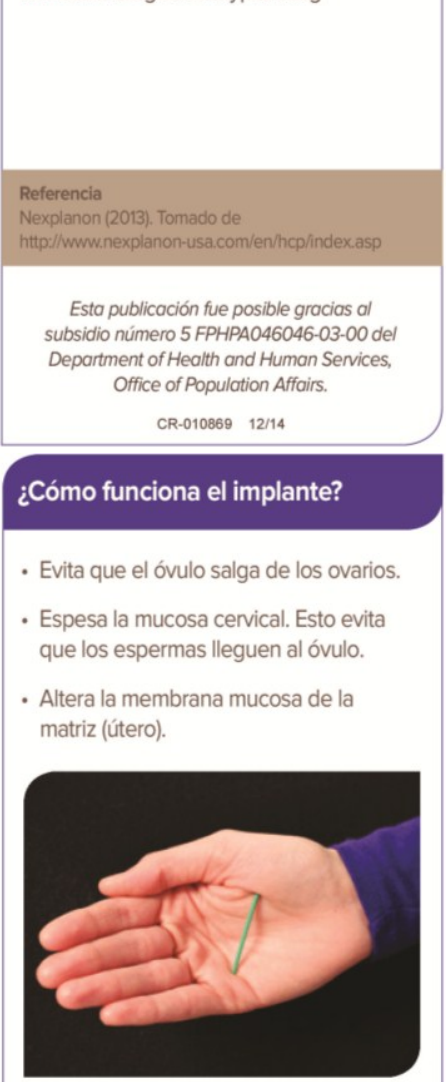

¿Por qué debería elegir un implante?

- Dura hasta 3 años.

- No tiene que acordarse de nada diariamente, semanalmente ni mensualmente.

- Se coloca en un lugar disimulado del brazo.

- Es muy eficaz.

- Su proveedor puede retirarlo.

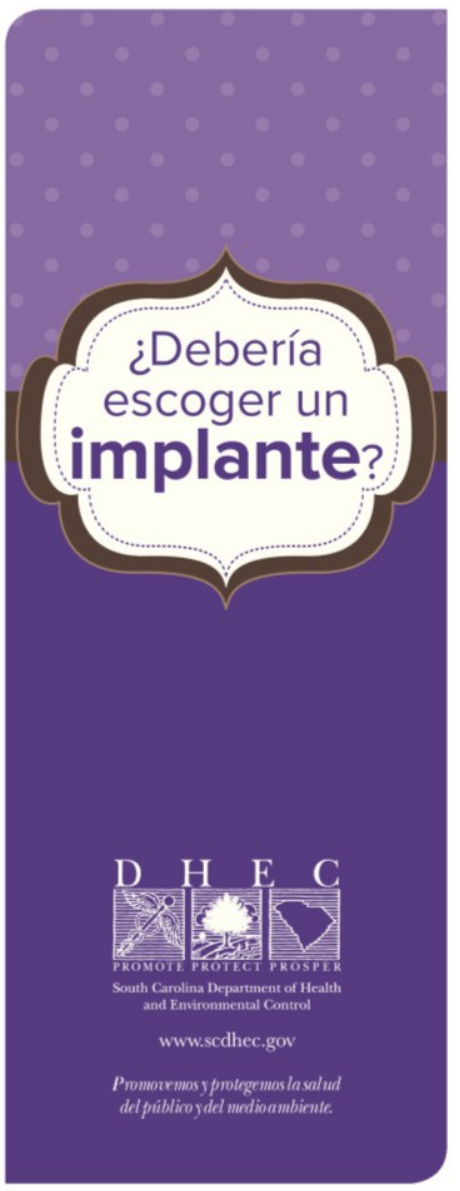

¿Cómo se inserta el implante?

1. Le ponen un poco de anestésico en el brazo en el que se colocará el implante.

2. El implante se coloca justo debajo de la piel.

3. Le vendan el brazo a presión alrededor del el implante.

La inserción solo toma unos minutos.

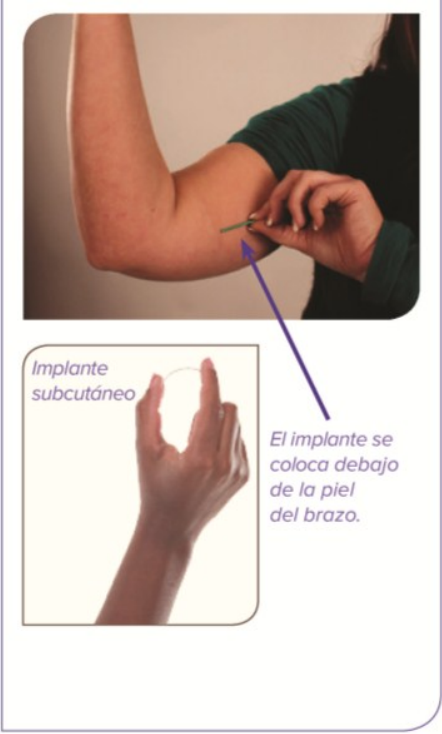

Figure 3. Shared Decision Aid, Spanish Language: “¿Debería escoger un implante?” [30]. 


\section{¿Cómo afectará mi período un DIU?}

- Es posible que con el DIU hormona observe cambios en sus períodos o que no tenga períodos.

- Es posible que con el DIU no hormonal sus períodos sean más prolongados o más copiosos. Este sangrado es normal.

- La mayoría de las mujeres no deja de usar el DIU debido a alteraciones en su menstruación.

\section{Otros efectos secundarios posibles}

Estos efectos secundarios son raros

- dolor estomacal o pélvico

- quistes en los ovarios

- se produce un orificio en el útero (matriz) o en el cuello del útero

- el DIU puede quedar atrapado en la pared del útero (matriz)

- infección pélvica

- embarazo ectópico (tener el embarazo en las trompas)

¿Qué es un dispositivo intrauterino (DIU)?

- Es una pieza de plástico en forma de T que se coloca dentro del útero (matriz).

- Dura entre 3 y 10 años.

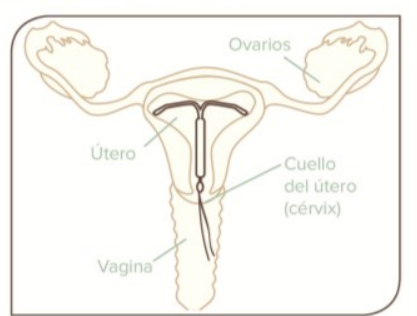

\section{Existen dos tipos de DIU.}

Dispositivo intrauterino (DIU) hormonal

- Contiene una hormona que previene el embarazo.

- Dura entre 3 y 5 años.

- Tiene una eficacia de más del $99 \%$.

Dispositivo intrauterino (DIU) no hormonal:

- Contiene cobre.

- Dura hasta 10 años.

- Tiene una eficacia de más del $\mathbf{9 9 \%}$

Figure 4. Shared Decision Aid, Spanish Language: “¿Debería escoger un dispositivo intrauterino(DIU)?" [31].
¿Entre cuáles otros métodos anticonceptivos puedo elegir?

- esterilización

- implante

- inyección anticonceptiva

- anillo anticonceptivo

- parche anticonceptivo

- pildoras anticonceptivas

- condones

- planificación familiar natural

¿Necesita más información?

Comuníquese al departamento local de salud pública.

www.scdhec.gov/familyplanning

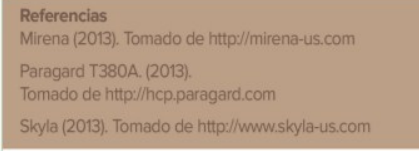

Esta publicación fue posible gracias al subsidio número 5 FPHPA046046-03-00 del Office of Population Affairs. CR-010870 $\quad 12 / 14$

\section{¿Cómo funcionan los DIU} hormonales?

- Espesan la mucosa cervical

- Disminuyen la movilidad de los espermatozoides

- Adelgazan la membrana mucosa del útero (matriz)

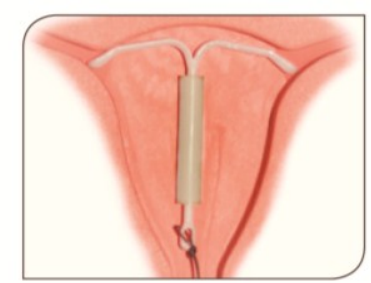

¿Cómo funcionan los DIU no hormonales?

- Impiden que los espermatozoides lleguen al óvulo y lo fecunden.

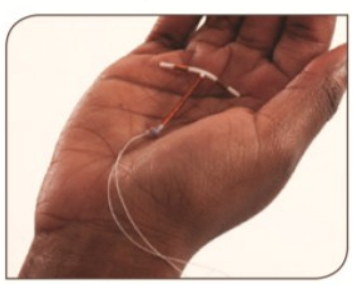
Department of Health and Human Services,

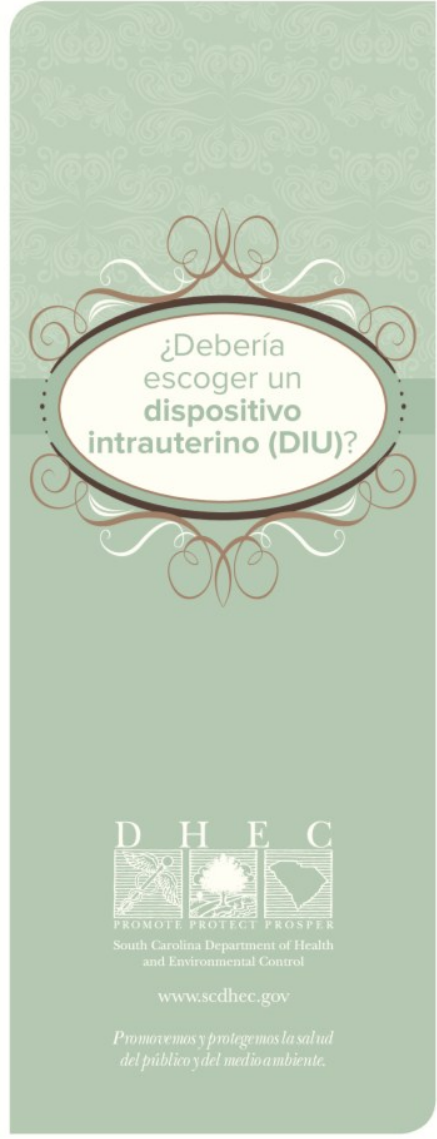

¿Por qué debería elegir un DIU?

- Dura entre 3 y 10 años.

- No tiene que acordarse de tomar nada diariamente, semanalmente ni mensualmente.

- Solo tiene que revisar su DIU una vez al mes.

- Es muy eficaz.

- Lo puede retirar su proveedor de atención médica.

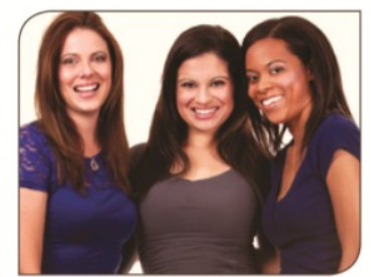

¿Cómo se coloca un DIU?

- Se introduce en el útero (matriz) a través de la vagina.

- Esto se puede hacer en el departamento de salud o en el consultorio de su proveedor.

- Tomará solamente unos minutos.

- Es posible que tenga algunos cólicoso manchas de sangre durante algunos días. 
In April 2014 a brief educational intervention was provided to the staff nurses and nurse practitioners about the shared decision aids, prior to their use in the five clinics. The nurses and nurse practitioners viewed a 15-min evidence-based presentation on LARCs, shared decision aids, and the practice improvement project itself; the presentation was designed by author TPG. Nursing staff attendance was verified by the nursing site supervisors, and there was $100 \%$ compliance in the training. The shared decision aids were added to routine care, used in a non-directive, collaborative approach appropriate to shared decision making. The nurses and nurse practitioners reviewed LARC choices with patients during patient encounters, utilizing the shared decision aids in the clinic setting to assist with responding to patient questions and clarifying information about procedures. Patients could also bring the shared decision aids home if desired to review further before selecting their chosen method of contraception.

\section{Results and Discussion}

During the study, 3484 women were approached. The total number of pre-intervention patients receiving contraceptive counseling for the months of 18 February through April 2014 (no shared decision aids) versus post-intervention data May through 19 July 2014 (use of shared decision aids) is compiled in Table 1. The total number of LARC insertions increased from 56 LARCs pre-intervention $(n=56$, $1.7 \%$ ) to 101 LARCs post-intervention ( $n=101,2.9 \%$ ) (see Figure 5). A chi-square test of independence comparing the pre-intervention (no shared decision aid) and post-intervention (use of shared decision aid) for utilization of LARCs showed statistically significant results $\left(\chi^{2}=12.23\right.$ with 1 degree of freedom, $p<0.005)$.

The utilization of contraceptive implants increased from 30 insertions pre-intervention to 63 insertions post-intervention, which corresponds to an increase from $0.9 \%(n=30)$ prior to the intervention to $1.8 \%(n=63)$ following the intervention. The number of IUDs grew from 26 IUDs pre-intervention to 38 IUDs post-intervention, which is a slight increase from $0.8 \%(n=26)$ to $1.1 \%$ $(n=38)$ of total patients. The IUDs utilized were the non-hormonal IUDs and hormonal Mirena IUDs. The Mirena IUDs were inserted the majority of the time; only 5 Paragard IUDs were inserted during the study. A chi square test of independence comparing the choice of IUD versus implants was not statistically significant $\left(\chi^{2}=1.15\right.$ with 1 degree of freedom, $\left.p>0.25\right)$. In addition, no patients had the LARCs removed during the study period.

Table 1. Total Number of Implants and IUDs Inserted at Five Public Health Sites.

\begin{tabular}{ccccccc}
\hline & Site 1 & Site 2 & Site 3 & Site 4 & Site 5 & Total \\
\hline Pre-intervention & $\mathrm{n}_{\text {pre }}=700$ & $\mathrm{n}_{\text {pre }}=495$ & $\mathrm{n}_{\text {pre }}=382$ & $\mathrm{n}_{\text {pre }}=1077$ & $\mathrm{n}_{\text {pre }}=680$ & $\mathrm{n}_{\text {pre }}=3334$ \\
Implants & $12(1.7 \%)$ & $5(1.0 \%)$ & $0(0 \%)$ & $6(0.6 \%)$ & $7(1.0 \%)$ & $30(0.9 \%)$ \\
IUDs & $1(0.1 \%)$ & $1(0.2 \%)$ & $3(0.8 \%)$ & $16(1.5 \%)$ & $5(0.7 \%)$ & $26(0.8 \%)$ \\
Total LARCs & $13(1.9 \%)$ & $6(1.2 \%)$ & $3(0.8 \%)$ & $22(2.0 \%)$ & $12(1.8 \%)$ & $56(1.7 \%)$ \\
Post-intervention & $\mathrm{n}_{\text {post }}=691$ & $\mathrm{n}_{\text {post }}=509$ & $\mathrm{n}_{\text {post }}=504$ & $\mathrm{n}_{\text {post }}=1100$ & $\mathrm{n}_{\text {post }}=680$ & $\mathrm{n}_{\text {post }}=3484$ \\
Implants & $15(2.2 \%)$ & $12(2.4 \%)$ & $4(0.8 \%)$ & $17(1.6 \%)$ & $15(2.2 \%)$ & $63(1.8 \%)$ \\
IUDs & $4(0.6 \%)$ & $4(0.8 \%)$ & $3(0.6 \%)$ & $20(1.8 \%)$ & $7(1.0 \%)$ & $38(1.1 \%)$ \\
Total LARCs & $19(2.8 \%)$ & $16(3.2 \%)$ & $7(1.4 \%)$ & $37(3.4 \%)$ & $22(3.2 \%)$ & $101(2.9 \%)$ \\
\hline
\end{tabular}




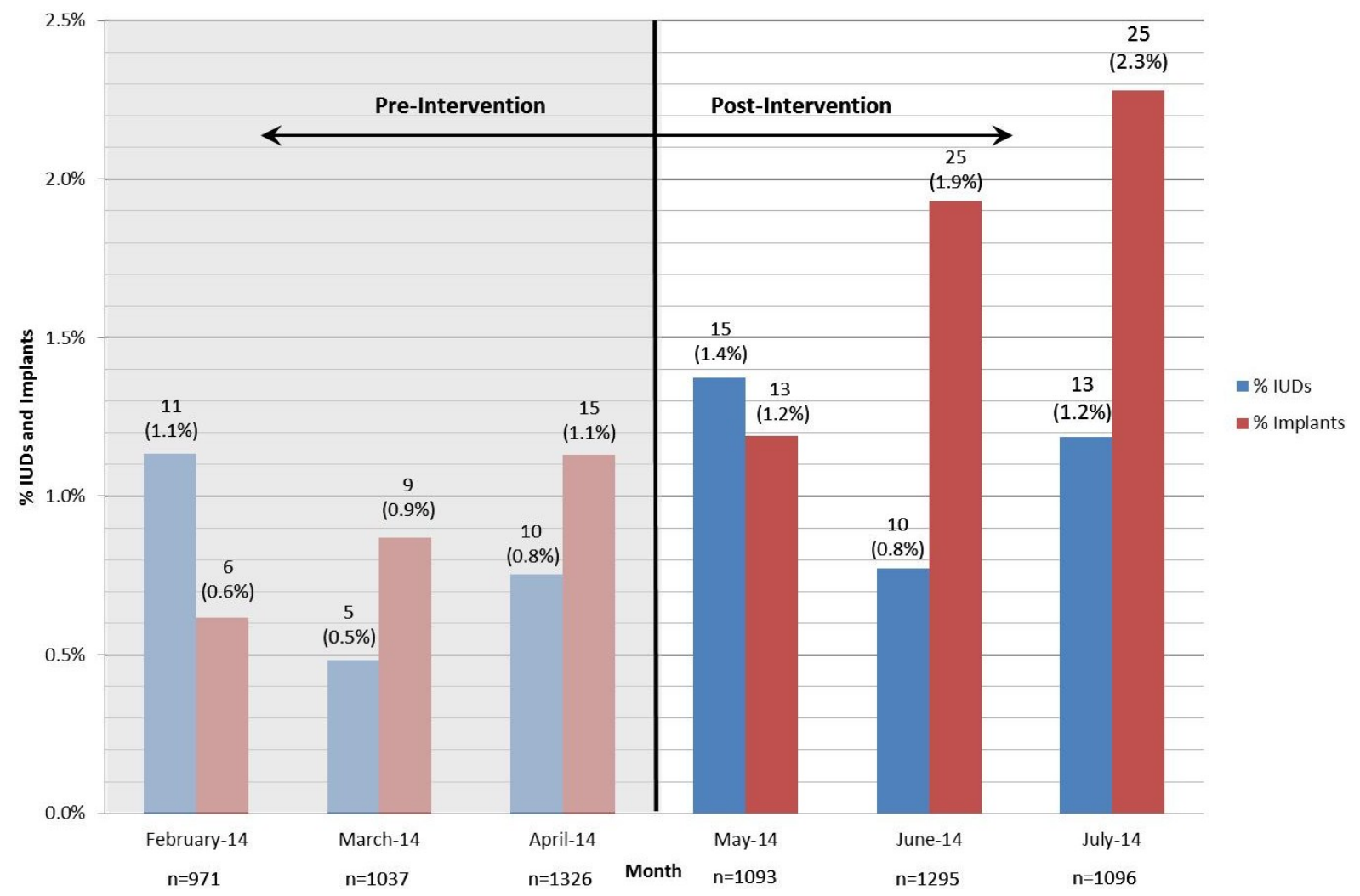

Figure 5. Summary Graph for LARCs Inserted at Five Public Health Sites.

Informal feedback from patients and staff occurred spontaneously during the course of this project. Many patients provided positive statements on use of the shared decision aids for LARCs, including that they "liked the pictures" and the decision aids were "easy to understand." The nurses and nurse practitioners had a similar positive experience, stating that the shared decisions aids were "helpful in counseling patients" and "allowed patients to make more informed decisions".

The clinics do not have nurse practitioner availability on each day of the week, so that is a barrier to same-day insertions. The clinics provide LARCS on a sliding-fee scale, and they also accept private insurance plans and all forms of Medicaid. The clinics have LARCS stocked and easily available for insertions. The clinics have adopted quick starts to LARCs when nurse practitioners are on site. IUDs can be inserted when patients are not on their menses, and STD testing can be performed at the time of insertion.

The combined five sites showed an increase in utilization of LARCs during the time period that shared decision aids were used, with the greatest increase in LARCs coming from the use of contraceptive implants. Informally, implementation was well accepted by providers, staff and patients. These results support the use of shared decision aids, which may provide patients with more information, thus likely improving women's ability to make more knowledgeable decisions regarding LARCs. This resource has been adopted for statewide use in all public health clinics.

Strengths of the project included the positive agency and nursing staff and nursing provider support for the quality improvement project. Once the shared decision aids were developed and approved, the costs to the sites were minimal since the shared decision aids were provided to all clinic sites at no cost; implementation of this project only required obtaining printed decision aid brochures for distribution to patients, and a brief educational intervention for staff. In addition, the use of the shared decision aids did not place any additional time demands on the nursing staff or nurse practitioner providers. 
A limitation of the project included a short post-implementation time frame of 3 months. A longer project might provide more robust data to better demonstrate changes in the percentage of LARC insertions. There are small numbers of overall of LARCs inserted, and staffing accounts for some of the variability between locations. Nurse practitioner availability for performing procedures is another factor that may influence LARC insertion rates, since some of the clinic locations have a nurse practitioner only once a week or less. The sites with more nurse practitioner access could provide same-day insertions, while the sites with clinicians less frequently had to schedule insertions. In addition, the baseline knowledge of LARCS was not obtained. This project only considers the variable of introducing shared decision making via the use of printed decision aids. However, many factors may influence women's choice of contraceptive methods, including the opinions of friends, partners, family, and information from the media [32]. In addition, costs, side effects, confidentiality of care, knowledge about methods, perceived risk of pregnancy, use of alcohol, and lack of planning affect contraceptive decisions [33].

The higher use of implants compared to IUDs may be related to patient preference and or increased clinician comfort with implants. Further studies need to be done to determine the reasons for the differences in types of LARCs inserted.

The utilization of LARCs in this project increased from $1.9 \%$ to $2.7 \%$. However, this is much lower than United States and global utilization of LARCs. In the United States from 2006 to 2010, 5.6\% of women used IUDs [26], while $3.4 \%$ of women worldwide used contraceptive implants and contraceptive injections and $15.5 \%$ of women utilized IUDs. There is a need to consider ways to remove barriers to LARC usage in this setting, including increased provider availability for same-day LARC insertions.

\section{Conclusions}

Our project provides evidence that the use of shared decision aids was an intervention that may have improved the use of LARCs at the five public health sites. Further studies need to investigate potential benefits from including shared decision aids in regular care for other types of healthcare services, both in the public and private setting. If the benefits of using shared decision aids are validated by such research, we advocate for making their use part of the standard of care.

\section{Acknowledgments}

The author wishes to acknowledge Catherine McCaskill, MSN, Pee Dee Region Program Manager at the South Carolina Department of Health and Environmental Control; Krystle Benton, BSN, Pee Dee Region Preventive Health Program Manager at the South Carolina Department of Health and Environmental Control; Sharon Walters, MSN, Nurse Practitioner/Manager of Student Health Services at Francis Marion University; Sharon M. Bond, PhD, CNM, FACNM, Associate Professor at the Medical University of South Carolina; and Khalil Demonbreun, DNP, Instructor at the Medical University of South Carolina for their guidance and assistance with this project. 


\section{Author Contributions}

Tracy P. George conceived the project based on her professional experience as a nurse practitioner and this project was part of her doctoral program work; she also designed the shared decision aids, obtained Institutional Review Board approval, oversaw the implementation of the shared decision aids at five clinical sites (including inservice for staff), gathered data from the electronic patient information system, and assisted with the manuscript. Claire DeCristofaro assisted with design of the project, identifying supporting resources and references, organizing the data and writing the manuscript. Bonnie P. Dumas assisted with design of the project, organizing and analyzing data, and writing the manuscript. Pamela F. Murphy provided additional data analysis and writing of the manuscript.

\section{Conflicts of Interest}

The authors declare no conflict of interest.

\section{References}

1. Glass, K.E.; Wills, C.E.; Holloman, C.; Olson, J.; Hechmer, C.; Miller, C.K.; Duchemin, A.-M. Shared decision making and other variables as correlates of satisfaction with health care decisions in a United States national survey. Patient Educ. Couns. 2012, 88, 100-105.

2. Clark, N.M.; Nelson, B.W.; Valerio, M.A.; Gong, Z.M.; Taylor-Fishwick, J.C.; Fletcher, M. Consideration of Shared Decision Making in Nursing: A Review of Clinicians' Perceptions and Interventions. Open Nurs. J. 2009, 3, 65-75.

3. Wirtz, V.; Cribb, A.; Barber, N. Patient-doctor decision-making about treatment within the consultation-A critical analysis of models. Soc. Sci. Med. 2006, 62, 116-124.

4. O'Connor, A.M. Using decision aids to help patients navigate the "grey zone" of medical decision-making. Can. Med. Assoc. J. 2007, 176, 1597-1598.

5. O'Connor, A.M.; Wennberg, J.E.; Legare, F.; Llewellyn-Thomas, H.A.; Moulton, B.W.; Sepucha, K.R.; Sodano, A.G.; King, J.S. Toward the "Tipping Point": Decision aids and informed patient choice. Health Aff. (Millwood) 2007, 26, 716-725.

6. French, R.S.; Wellings, K.; Cowan, F.M. How can we help people to choose a method of contraception? The case for contraceptive decision aids. J. Fam. Plan. Reprod. Health Care 2009, 35, 219-220.

7. The SHARE Approach. Available online: http://www.ahrq.gov/professionals/education/curriculumtools/shareddecisionmaking/index.html (accessed 24 January 2015).

8. Trussell, J.; Henry, N.; Hassan, F.; Prezioso, A.; Law, A.; Filonenko, A. Burden of unintended pregnancy in the United States: Potential savings with increased use of long-acting reversible contraception. Contraception 2013, 87, 154-161.

9. Centers for Disease Control and Prevention. U.S. Medical Eligibility Criteria for Contraceptive Use, 2010. Available online: http://www.cdc.gov/mmwr/pdf/rr/rr59e0528.pdf (accessed on 28 March 2015).

10. American College of Obstetricians and Gynecologists Committee on Gynecologic Practice. Long-Acting Reversible Contraception Working Group ACOG Committee Opinion No. 450: Increasing use of contraceptive implants and intrauterine devices to reduce unintended pregnancy. Obstet. Gynecol. 2009, 114, 1434-1438. 
11. Blumenthal, P.D.; Voedisch, A.; Gemzell-Danielsson, K. Strategies to prevent unintended pregnancy: Increasing use of long-acting reversible contraception. Hum. Reprod. Update 2011, 17, 121-137.

12. Jones, J.; Mosher, W.; Daniels, K. Current contraceptive use in the United States, 2006-2010, and changes in patterns of use since 1995. Available online: http://www.cdc.gov/nchs/data/nhsr/nhsr060.pdf (accessed on 7 April 2015).

13. Espey, E.; Ogburn, T. Long-acting reversible contraceptives: Intrauterine devices and the contraceptive implant. Obstet. Gynecol. 2011, 117, 705-719.

14. Dempsey, A.R.; Billingsley, C.C.; Savage, A.H.; Korte, J.E. Predictors of long-acting reversible contraception use among unmarried young adults. Am. J. Obstet. Gynecol. 2012, doi:10.1016/j.ajog.2012.02.014.

15. Landry, D.J.; Wei, J.; Frost, J.J. Public and private providers' involvement in improving their patients' contraceptive use. Contraception 2008, 78, 42-51.

16. Arrowsmith, M.E.; Aicken, C.R.; Saxena, S.; Majeed, A. Strategies for improving the acceptability and acceptance of the copper intrauterine device. In Cochrane Database of Systematic Reviews; John Wiley \& Sons, Ltd.: Hoboken, NJ, USA, 2012.

17. Brown, M.K.; Auerswald, C.; Eyre, S.L.; Deardorff, J.; Dehlendorf, C. Identifying counseling needs of nulliparous adolescent intrauterine contraceptive users: A qualitative approach. J. Adolesc. Health 2013, 52, 293-300.

18. Madden, T.; Mullersman, J.L.; Omvig, K.J.; Secura, G.M.; Peipert, J.F. Structured contraceptive counseling provided by the Contraceptive CHOICE Project. Contraception 2013, 88, 243-249.

19. Secura, G.M.; Allsworth, J.E.; Madden, T.; Mullersman, J.L.; Peipert, J.F. The Contraceptive CHOICE Project: Reducing barriers to long-acting reversible contraception. Am. J. Obstet. Gynecol. 2010, doi:10.1016/j.ajog.2010.04.017.

20. Winner, B.; Peipert, J.; Zhao, Q.; Buckel, C.; Madden, T.; Allsworth, J.; Secura, G. Effectiveness of long-acting reversible contraception. N. Engl. J. Med. 2012, 366, 1998-2007.

21. Secura, G.M.; Madden, T.; McNicholas, C.; Mullersman, J.; Buckel, C.M.; Zhao, Q.; Peipert, J.F. Provision of no-cost, long-acting contraception and teenage pregnancy. N. Engl. J. Med. 2014, 371, 1316-1323.

22. Dehlendorf, C.; Levy, K.; Kelley, A.; Grumbach, K.; Steinauer, J. Women's preferences for contraceptive counseling and decision making. Contraception 2013, 88, 250-256.

23. Ricketts, S.; Klingler, G.; Schwalberg, R. Game Change in Colorado: Widespread Use of Long-Acting Reversible Contraceptives and Rapid Decline in Births among Young, Low-Income Women. Perspect. Sex. Reprod. Health 2014, 46, 125-132.

24. Sharon Walters. South Carolina Department of Health and Environmental, Columbia, SC, USA. Personal Communication, 2013.

25. South Carolina Campaign to Prevent Teen Pregnancy 20 Years of Progress Map. Available online: http://teenpregnancysc.org/UserFiles/teenpregsc/Documents/20\%20Years\%20of\%20Progress $\% 20$ Map.pdf (accessed on 28 June 2014).

26. U.S. Department of Health and Human Services Program Guidelines for Project Grants for Family Planning Services. Available online: http:/www.hhs.gov/opa/pdfs/2001-ofp-guidelines-complete.pdf (accessed on 23 April 2014). 
27. South Carolina Department of Health and Environmental Control Client educational services. Available online: http://ww2.dhecnet.com/hs/policy/fp/Client\%20Educational\%20Services\%20saf.pdf (accessed on 23 April 2014).

28. South Carolina Department of Health and Environmental Control. Should I Choose an Implant? Available online: http://www.scdhec.gov/library/CR-010847.pdf (accessed on 7 April 2015).

29. South Carolina Department of Health and Environmental Control. Should I Choose an IUD? Available online: http://www.scdhec.gov/library/CR-010848.pdf (accessed on 7 April 2015).

30. South Carolina Department of Health and Environmental Control. "¿Debería escoger un implante?"Available online:http://www.scdhec.gov/library/CR-010869.pdf (accessed on 7 April 2015)

31. South Carolina Department of Health and Environmental Control. “¿Debería escoger un dispositivo intrauterine (DIU)?” Available online: http://www.scdhec.gov/library/CR-010870.pdf (accessed on 7 April 2015)

32. Yee, L.; Simon, M. The Role of the Social Network in Contraceptive Decision-making among Young, African American and Latina Women. J. Adolesc. Health 2010, 47, 374-380.

33. Campo, S.; Askelson, N.M.; Spies, E.L.; Losch, M. Preventing Unintended Pregnancies and Improving Contraceptive Use among Young Adult Women in a Rural, Midwestern State: Health Promotion Implications. Women Health 2010, 50, 279-296.

(C) 2015 by the authors; licensee MDPI, Basel, Switzerland. This article is an open access article distributed under the terms and conditions of the Creative Commons Attribution license (http://creativecommons.org/licenses/by/4.0/). 